In this issue:

\section{Publishers Settle Suit with Copy Service}

Continuing Education:

Getting Quality

for the Price

Professional Survival:

Crowd of Strangers:

ALA Conferences

The Rare Book Librarian . . . 166

Letters . . . . . . . . . . . . . . . 167

ACRL Chapters . . . . . . . . 168

News from the Field . . . . . . 170

People ..............173

Publications ............ 179

Calendar ............. 183

Classified Advertising 186
College \& Research Libraries News is published by the Association of Coilege and Research Libraries, a division of the American Library Association, as 11 monthly (combining July-August) issues, at $50 \mathrm{E}$. Huron St. Chicago, IL 60511 Annual subscription $\$ 5$, or to members of the division $\$ 2.50$ included in dues. Single copies and back issues, $\$ 2$ each Second-class postage applied for at Chicago. Illinois, and at additional mailing offices (ISSN 0099-0086).

Editor: Jeffrey T. Schwedes, ACRLIALA, $50 \mathrm{E}$. Huron St. Chicago, IL 60611; (312) 944-6780, Ext. 286. President ACRL: Le Moyne W. Anderson. Executive Secretary, ACRL: Jule A. Carroll Virgo.

Production and circulation affice: $50 \mathrm{E}$. Huron St. Chicago L 60611. Display advertising should be sent to Leora Swiech Advertising Traffic Coordinator, ALA, at above address. Send classilled ads to ACRL. Change of address and subscription arders should be addresced to College \& Research Libraries News. for receipt at the above address at least wo months be News, for receipt at the above address at least wo months be ore the publication date of the effective issue.

Inclusion of an article or advertisement in C\&RL News does not constitute official endorsement by ACRL or ALA

A partial list of the services indexing or abstracting the contents of C\&RL News includes: Current Contents. Social \& Be

havioral Sciences: Current Index to Journals in Education: Information Science Abstracts; Library \& Intormation Science Abstracts: Library Literature, and Social Sciences Citation index.

(C)American Library Association 1980. All material in this journal subject to copyright by the American Library Association may be photocopied for the noncommercial purpose of scientific or educational advancement. compliance with universities and expects to step up the intensity of these activites now that the Gnomon case has satisfactorily been settled."

The four copying facilities owned by the Gnomon Corporation are located near Harvard, Yale, Cornell, and Pennsylvania State Universities. The seven publishers that brought the suit were Basic-Books-Harper \& Row; CBS, Inc.-Holt. Rinehart \& Winston; McGraw-Hill; Nelson-Hall; Prentice-Hall; Princeton University Press; and John Wiley \& Sons.

\section{ACRL RECEPTION IN NEW YORK}

The ACRL reception at the New York Conference will be held at Low Rotunda, Columbia University, on Tuesday July 1 from 6:00 to 8:00 p.m. The reception will follow the ACRL membership and program meetings (2:00 to $5: 30 \mathrm{p.m}$.) in the Waldorf-Astoria Hotel.

What is the best way to travel from the Waldorf-Astoria to the Columbia campus? Your best bet may be to share a taxi. New York cabs charge only for the ride, not for extra passengers. If you can squeeze three or four passengers into your cab, you may be able to keep your share of the fare under $\$ 2$.

Have the cab take you to one of the main Columbia University gates - either at Broadway and 116th Street or at Amsterdam and 116th Street. On the Columbia campus, 116th Street becomes College Walk. If you enter the campus at either the Broadway or Amsterdam gates and proceed down College Walk, you will soon come to the Low Rotunda-standing directly across from the Butler Library

If you prefer to take a bus, walk one block from the Waldorf-Astoria (across Park Avenue) to Madison Avenue. There, you can catch a Madison Avenue bus (number four) to 116 th Street and Riverside Drive and walk two blocks to the campus gate at 116 th and Broadway.

If your starting point is one of the Sixth Avenue hotels, you can take the $\mathbf{M - 5}$ bus on Sixth Avenue to 116th Street and Riverside and walk to the Broadway gate. Or you can catch the Broadway Line of the IRT subway (train number 1) at Forty-Second Street and Broadway, Fiftieth Street and Broadway, or Columbus Circle (Fiftyninth and Broadway). Get off the train at 116th Street and walk right into the Broadway gate of the University.

\section{Notice to Subscribers}

The July/August issue of C $b R L$ News will be published in July. 


\section{Only a rare bestseller becomes a classic.}

Few

bestsellers

withstand the test of

time. Titles and story lines are soon forgotten, lost in the piles of the once-popular.

Occasionally a classic emerges - a work so strong and fine that its reputation grows to a status beyond popularity.

Bookjobbers are often like bestsellers - gradually fading in importance and quality. Yankee Book Peddler is a bookjobber that intends to stay on the bestseller list for a long, long time.

Over the years we've held to a rare story line based on excellence, attention to detail and service. We have established a reputation as one of the finest library bookjobbers

\section{of university press,}

scientific, business and other scholarly publications in the United States.

Remaining a bestseller is not enough; we hope to become a classic in the 1980 's by giving you even better service:

$\square$ New warehouse and distribution facilities for faster order fulfillment.

$\square$ A North American Sales Manager based in the Midwest. $\square$ A publisher liason representative working with major New York area publishers.
Through close personal communication, expanded facilities and meticulous quality control, Yankee Book Peddler intends to stay on your bestseller list - plus earn a place in your collection of classics.
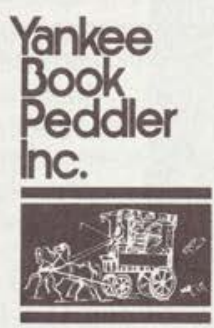

Yankee Book Peddler $\square$ Maple Street $\square$ Contoocook, New Hampshire 03229 $\square$ 603/746-3102 